Sri Lanka Journal of Urology, 2010, 11, 30-35

Urological Oncology Audit

\title{
Pattern of urological malignancies in 2010 - an audit from a tertiary referral centre
}

\author{
A. P. I. Prabath and S. A. S. Goonewardena \\ Department of Urology, National Hospital of Sri Lanka, Colombo.
}

Cancer is a major public health problem worldwide. Among various types of malignancies, genitourinary malignancies, except testicular cancer are notorious for causing high mortality and morbidity. Currently, 1 in 4 deaths in the United States is due to cancer. In USA, prostate cancer is the commonest cancer in men and accounts for the second commonest cause for the cancer death in men (1). Patterns of these cancers are variable according to time, region, and ethnic groups. We conducted an audit on the incidence of urological malignancies in a single urological unitat the National Hospital of Sri Lanka.

\section{Method}

Newly diagnosed cases of all histopathologically confirmed urological malignancies in the year 2010 were collected from the clinic notes and operation register retrospectively and analysed.

\section{Results}

There were 76 urological malignancies diagnosed in the year 2010 and Table 1 shows their age and sex distribution.

In this study, bladder cancer was the commonest urological malignancy accounting for $42.10 \%$ of all the cases. Their median age was 67.5 years (range 50 - 90) and the male to female ratio was 3.7:1 (Table 1). Three fourth of them had painless or painful macroscopic haematuria at presentation (Table 2).

Table 1. Age and sex distribution

\begin{tabular}{|l|c|c|c|c|c|}
\hline Site of malignancy & $\begin{array}{c}\text { Number of } \\
\text { patients }\end{array}$ & $\begin{array}{c}\text { \% of each } \\
\text { malignancy }\end{array}$ & Male & Female & $\begin{array}{c}\text { Average age } \\
\text { years }\end{array}$ \\
\hline Bladder & 32 & 42.10 & 25 & 7 & 67.51 \\
\hline Upper urinary tract & 1 & 01.31 & 1 & & 42 \\
\hline Prostate & 31 & 40.78 & 31 & - & 70.7 \\
\hline Kidney (RCC) & 9 & 11.84 & 8 & 1 & 57.44 \\
\hline Penis & 2 & 02.63 & 2 & - & 53.5 \\
\hline Testis & 1 & 01.31 & 1 & - & 20 \\
\hline Total & 76 & 100.00 & 68 & 8 & 66.7 \\
\hline
\end{tabular}


Table 2. Clinical presentation of bladder cancer and number of patients

\begin{tabular}{|l|c|}
\hline Presentation & No of patients \\
\hline Haematuria (painless/painful) & 21 \\
\hline Haematuria + LUTS & 4 \\
\hline LUTS & 6 \\
\hline Liver secondaries & 1 \\
\hline Lower abdominal pain & 1 \\
\hline
\end{tabular}

Histological type, grade and pathological stage of bladder cancers are shown in Table 3. Out of 23 cases of nonmuscle invasive transitional cell carcinoma (TCC), 14 were low grade. All muscle invasive cancer in this study were high grade. There were two pure squamous cell carcinoma, one TCC with squamous differentiation and one sarcomatoid tumour in the study.

Prostate carcinoma was the second commonest malignancy. The median age at presentation was 70.7 years (5484). While the commonest presentation was lower urinary tract symptoms (18 cases) acute urine retention was the second commonest (5 cases). All patients with prostate carcinoma presented with locally advance disease except three patients who presented with symptoms of distant metastases. Histologically all were small acinar type adenocarcinoma except one case of papillary TCC. The Gleason sum score was 8 or more in 20 patients (64.5\%). More than half of the patients had their serum PSA $>60 \mathrm{ng} / \mathrm{l}$.

All nine cases of renal cell carcinoma were clear cell variety except one being chromophobe. Their mean age at presentation was 57.4 years (53-72) and male to female ratio was 9 to 1 .Six patients had macroscopic haematuria at presentation while two cases were detected incidentally. According to the TNM classification, there were 3,4 and 2 of pT1, pT2 and pT3a respectively.

Table 3. Histological type, grade and pathological stage

\begin{tabular}{|c|c|c|c|c|c|}
\hline Type & Stage & Grade & \multicolumn{2}{|c|}{ Number } & $\%$ of patients \\
\hline \multirow[t]{6}{*}{ TCC } & \multirow[t]{2}{*}{$\mathrm{pTa}$} & Low grade & 9 & \multirow[t]{2}{*}{10} & \multirow[t]{2}{*}{30.30} \\
\hline & & High grade & 1 & & \\
\hline & \multirow[t]{2}{*}{ pT1 } & Low grade & 5 & \multirow[t]{2}{*}{13} & \multirow[t]{2}{*}{39.39} \\
\hline & & High grade & 8 & & \\
\hline & \multirow[t]{2}{*}{ pT2 } & Low grade & 0 & \multirow[t]{2}{*}{7} & \multirow[t]{2}{*}{21.21} \\
\hline & & High grade & 7 & & \\
\hline \multirow[t]{2}{*}{$\mathrm{SCC}$} & pT1 & MD* & 1 & 2 & \multirow[t]{2}{*}{06.06} \\
\hline & pT2 & MD* & 1 & & \\
\hline Sarcomatoid carcinoma & & & 1 & 1 & 03.03 \\
\hline
\end{tabular}

${ }^{*}$ Moderately differentiated 
Table 4. Clinicopathological presentation of prostate carcinoma

\begin{tabular}{|c|c|c|c|c|c|}
\hline No. & Age & Presentation & DRE & Serum PSA & Gleason sum score \\
\hline 1 & 79 & LUTS & M & 43.4 & $10(5+5)$ \\
\hline 2 & 65 & LUTS & M & $>100$ & $9(5+4)$ \\
\hline 3 & 72 & LUTS & $\mathrm{E}$ & 250 & $9(5+4)$ \\
\hline 4 & 82 & LUTS & M & $>2000$ & $6(3+3)$ \\
\hline 5 & 64 & LUTS & M & $>400$ & $7(4+3)$ \\
\hline 6 & 54 & LUTS & M & 271 & $8(4+4)$ \\
\hline 7 & 83 & ARU & M & 33.3 & $9(5+4)$ \\
\hline 8 & 69 & LUTS & $\mathrm{M}$ & 23.7 & $8(4+4)$ \\
\hline 9 & 67 & LUTS & M & $>100$ & $8(4+4)$ \\
\hline 10 & 71 & LUTS & M & 957 & $7(3+4)$ \\
\hline 11 & 68 & LUTS & $\mathrm{E}$ & 306 & $9(5+4)$ \\
\hline 12 & 68 & LUTS & $\mathrm{E}$ & 4330 & $9(4+5)$ \\
\hline 13 & 69 & LUTS & M & 6.6 & $10(5+5)$ \\
\hline 14 & 67 & LUTS & M & 142 & $8(3+5)$ \\
\hline 15 & 65 & Vertebral metastasis & $\mathrm{M}$ & 23 & $8(3+5)$ \\
\hline 16 & 71 & Lower limb lymphoedema & M & $>100$ & $9(5+4)$ \\
\hline 17 & 66 & LUTS & $\mathrm{M}$ & 734 & $9(4+5)$ \\
\hline 18 & 73 & Cerebral metastasis & M & 30.6 & $7(4+3)$ \\
\hline 19 & 67 & ARU & M & 67 & $9(5+4)$ \\
\hline 20 & 71 & LUTS & $\mathrm{E}$ & 45.8 & $7(4+3)$ \\
\hline 21 & 74 & ARU & M & $>400$ & $9(4+5)$ \\
\hline 22 & 67 & LUTS & $\mathrm{E}$ & 18.8 & $6(3+3)$ \\
\hline 23 & 84 & ARU & M & 12.1 & $9(4+5)$ \\
\hline 24 & 68 & ARU & M & $>100$ & $7(3+4)$ \\
\hline 25 & 76 & LUTS & $\mathrm{M}$ & 6.75 & $9(5+4)$ \\
\hline 26 & 81 & Haematuria & B & 15.7 & $7(4+3)$ \\
\hline 27 & 74 & HPCR & M & 16.7 & $6(3+3)$ \\
\hline 28 & 65 & Haematuria & $\mathrm{E}$ & 6.8 & $9(4+5)$ \\
\hline 29 & 64 & LUTS & M & 13.2 & $9(5+4)$ \\
\hline 30 & 74 & Paraplegia & M & 3920 & $7(3+4)$ \\
\hline 31 & 74 & Lower limb lymphoedema & M & 4.1 & papillaryTCC \\
\hline
\end{tabular}

LUTS $=$ Lower Urinary Tract Symptoms, ARU = Acute Urinary Retention, HPCR $=$ High Pressure Chronic Retention. 
Table 5. Clinical presentation of renal malignancy and number of patients

\begin{tabular}{|l|c|}
\hline Presentation & No of patients \\
\hline Haematuria & 4 \\
\hline Haematuria and loin pain & 1 \\
\hline Haematuria and LOW & 1 \\
\hline Anaemia & 1 \\
\hline Incidental & 2 \\
\hline
\end{tabular}

There was one testicular cancer in a 20-year old man which presented as a testicular mass and it was classic seminoma stage 1 .

Out of two penile cancers, one presented as phimosis while the other was detected during follow up for benign penile lesion. Both were histologically well differentiated and pathological stages were pT2 and pT1a.

\section{Discussion}

According to the 2010 cancer statistics, the commonest noncutaneous malignancy in USA men is carcinoma of the prostate accounting for $25 \%$ of all cancers and is the second commonest cause of cancer death i.e. $11 \%$ of all cancer death. Urinary bladder cancer, kidney and renal pelvis cancers are the 4th and 7th leading cancers in men respectively. Kidney and renal pelvis malignancy is the commonest urological malignancy in female and is the 8th leading cancer (1). According to the cancer statistic data 2005, prostate cancer, being 8th leading cancer ( $5 \%$ of all cancers), is the only urological malignancy included among the first ten leading cancers in Sri Lanka (2).

In our study, number of Pca was slightly less than that of bladder cancer. As the PSA based screen detected Pca is not included, actual number of Pca would be much greater.

In USA, Pca incidence in 2005 was 170 per 100000 population $(3,4)$. In Sri Lanka it was 3.1 in the same year (2). Worldwide, it is the fourth commonest male malignancy with great variation between countries and ethnic groups, Asia having the lowest incidence rate (1.9 cases per 100000 populationper year in Tianjin, China) while African-American having the highest (172 cases per 100000 populationper year) (5). Reason for such diversity would be due to access to and quality of health, accuracy of cancer registries and penetrance of PSA screening, environmental and genetic predisposition. Over the five year commencing from 2001 to 2005 , Pca incidence has fluctuated in Sri Lanka (250,297,259,273,303 respectively) (2).

Table 6. Comparison of age distribution of Pca at presentation in US, in Sri Lanka and in our study $(2,3)$

\begin{tabular}{|c|c|c|c|c|c|}
\hline \multirow{2}{*}{ Age } & \multicolumn{2}{|c|}{ Sri Lanka } & \multicolumn{2}{c|}{ Study group } & USA \\
\cline { 2 - 6 } & Number & Percentage & Number & Percentage & Percentage \\
\hline$<34$ & 0 & & 0 & 0 & 0 \\
\hline $35-44$ & 3 & 0.9 & 0 & 0 & 0.6 \\
\hline $45-54$ & 19 & 6.27 & 1 & 3.22 & 8.9 \\
\hline $55-64$ & 63 & 20.79 & 2 & 6.22 & 29.9 \\
\hline $65-74$ & 126 & 41.58 & 22 & 70.96 & 35.3 \\
\hline $75-84$ & 92 & 30.36 & 6 & 19.35 & 20.7 \\
\hline$>85$ & & & 0 & 0 & 4.6 \\
\hline
\end{tabular}


Table 7. Stage distribution and 5-year relative survival by stage at diagnosis for 1999-2006, all races, males (3)

\begin{tabular}{|l|c|c|}
\hline Stage at diagnosis & $\begin{array}{c}\text { Stage } \\
\text { distribution\% }\end{array}$ & $\begin{array}{c}\text { 5-year relative } \\
\text { survival (\%) }\end{array}$ \\
\hline Localized (confined to primary site) & 80 & 100 \\
\hline Regional (spread to regional lymphnodes) & 12 & 100 \\
\hline Distant (cancer has metastasized) & 4 & 30 \\
\hline (unstaged) & 3 & 75 \\
\hline
\end{tabular}

Table 8. Cancer incidence by the reporting year and site 2001-2005 in Sri Lanka (2)

\begin{tabular}{|l|c|c|c|c|c|c|}
\hline Site of malignancy & 2001 & 2002 & 2003 & 2004 & 2005 & Total \\
\hline Prostate & 250 & 297 & 259 & 273 & 303 & 1382 \\
\hline Bladder & 136 & 142 & 99 & 120 & 156 & 653 \\
\hline Kidney & 80 & 90 & 85 & 103 & 100 & 458 \\
\hline Penis & 75 & 63 & 69 & 44 & 73 & 324 \\
\hline Testis & 44 & 33 & 33 & 35 & 42 & 187 \\
\hline Total & 585 & 625 & 545 & 575 & 674 & 3004 \\
\hline
\end{tabular}

Above comparison shows that peak age group for Pca is 65-74 years in both study group and Sri Lankan study, in keeping with USA Pca incidence while median age for Pcain our study is higher (70.7 years) than that of USA (67 years).

In our study, all cases were advanced stage at diagnosis. Three patients presented with distantmetastases (one with hemiparesis following brain metastases and two with vertebral metastases). Two patients presented with unilateral lower limb lymphoedema indicating regional lymph node involvement.

The number of bladder cancers is slightly higher than that of prostate cancers in our study (32 vs 31). Similar study performed in the same unit for two year period from January 1994 to December 1995 shows higher incidence of bladder cancer (88 vs 62) (6). According to the Sri Lanka Cancer Registry, incidence of bladder cancer is much lower than that of prostate cancer (2) (Table 7). This difference is due to the fact that bladder cancer is almost exclusively managed by the urological surgeons at the start of the treatment while other cancers such as cancer of the prostate and kidney are predominantly managed by the general surgeons in Sri Lanka (6).

At presentation, approximately $75-85 \%$ of all patients with bladder cancer have non-muscle invasive disease, an almost similar finding (75\%) in our study also (7). However, the largest bladder cancer study performed in Sri Lanka shows that muscle invasive disease at presentation is seen in nearly half of the patients (8).

\section{References}

1. Jemal A, Siegel R, Xu J, Ward E. Cancer Statistics, 2010. CA Cancer J Clin 2010; 60; 277-300.

2. Jayanthi KGN, Somarathna L, Walpola N, et el. Cancer incidence Data: Sri Lanka Year 2001-2005. Cancer Registry 2009: 9. 
3. Altekruse SF, Kosary CL, Krapcho M, Neyman N, Aminou R, Waldron W, Ruhl J, Howlader N, Tatalovich Z, Cho H, Mariotto A, Eisner MP, Lewis DR, Cronin K, Chen HS, Feuer EJ, Stinchcomb DG, Edwards BK (eds). SEER Cancer Statistics Review, 1975-2007, National Cancer Institute.

4. Jemal A, Murray T, Ward E, Samuels A, Tiwari RC, Ghafoor A, Feuer EJ, Thun MJ.Cancer Statistics, 2005. CA Cancer J Clin 2005; 55: 10-30.

5. Campbell-Walsh Urology. WB Saunders, Philadelphia, PA, 2007; 2856 - 2857.
6. Goonewardena SAS, de Silva WAS. Pattern of urological malignancy in Sri Lanka: experience from a tertiary referral centre. Ceylon Medical Journal 1999; $44: 100-1$.

7. Babjuk M.Transurethral resection of non-muscleinvasive bladder cancer. European Urology 2009; 8: 542-8.

8. Goonewardena SAS, De Silva WAS, De Silva MVC. Bladder cancer in Sri Lanka: experience from a tertiary referral center. International Journal of Urology 2004; 11: 969-72.

\section{Authors}

A. P. I. Prabath, MBBS (Ruhuna), MD (Col), MRCS (Edin) Senior Registrar in Urology

Serozsha A. S. Goonewardena, MS (Col), FRCS (Eng), DUrol (Lond) Consultant Urological Surgeon

Department of Urology, National Hospital of Sri Lanka, Colombo. 